\title{
Do entrance fees crowd out donations for public goods? Evidence from a protected area in Costa Rica
}

Article in Environment and Development Economics · June 2014

DOI: $10.1017 /$ S1355770X14000485

CITATIONS

4

3 authors:

Francisco Alpizar

Wageningen University \& Research

103 PUBLICATIONS 1,847 CITATIONS

SEE PROFILE

Anna Nordén

Chalmers University of Technology

10 PUBLICATIONS 75 CITATIONS

SEE PROFILE

\section{READS}

56
Peter Martinsson

University of Gothenburg

120 PUBLICATIONS 3,854 CITATIONS

SEE PROFILE

Some of the authors of this publication are also working on these related projects:

REDD+ and community forestry View project 


\section{Environment and Development Economics}

http://journals.cambridge.org/EDE

Additional services for Environment and

Development Economics:

Email alerts: Click here

Subscriptions: Click here

Commercial reprints: Click here

Terms of use : $\underline{\text { Click here }}$

Environment and

Development

Economics

\section{Do entrance fees crowd out donations for public goods? Evidence from a protected area in Costa Rica}

Francisco Alpízar, Peter Martinsson and Anna Nordén

Environment and Development Economics / Volume 20 / Issue 03 / June 2015, pp 311 - 326 DOI: 10.1017/S1355770X14000485, Published online: 30 June 2014

Link to this article: http://journals.cambridge.org/abstract S1355770X14000485

How to cite this article:

Francisco Alpízar, Peter Martinsson and Anna Nordén (2015). Do entrance fees crowd out donations for public goods? Evidence from a protected area in Costa Rica. Environment and Development Economics, 20, pp 311-326 doi:10.1017/ S1355770X14000485

Request Permissions : $\underline{\text { Click here }}$ 


\title{
Do entrance fees crowd out donations for public goods? Evidence from a protected area in Costa Rica
}

\author{
FRANCISCO ALPÍZAR
}

Environment for Development (EfD) Center for Central America, CATIE, 7170 Turrialba, Costa Rica. Tel: (506) 2558-2215. Fax: (506) 2558-2625.

Email:falpizar@catie.ac.cr

\section{PETER MARTINSSON}

Department of Economics, University of Gothenburg, Sweden.

Email: peter.martinsson@economics.gu.se

\section{ANNA NORDÉN}

Department of Economics, University of Gothenburg, and Department of Physical Geography and Ecosystem Science, Lund University, Sweden.

Email: anna.norden@economics.gu.se

Submitted 21 May 2013; revised 31 January 2014; accepted 28 April 2014; first published online 30 June 2014

\begin{abstract}
In this paper, we investigate how different levels of entrance fees affect donations for a public good, a natural park. To explore this issue, we conducted a stated preference study focusing on visitors' preferences for donating money to raise funds for a protected area in Costa Rica given different entrance fee levels. The results reveal that there is incomplete crowding out of donations when establishing an entrance fee.
\end{abstract}

\section{Introduction}

All too often, important public goods, such as national parks and cultural institutions (e.g., museums and opera houses), find themselves under

The authors gratefully acknowledge financial support from Sida to the Environmental Economics Unit at the University of Gothenburg and to CATIE via the Environment for Development initiative, and from the Swedish Research Council (Vetenskapsrådet), Formas through the program Human Cooperation to Manage Natural Resources (COMMONS), and the Jan Wallander and Tom Hedelius Foundation. The authors thank Fredrik Carlsson, Gardner Brown, seminar participants at the University of Gothenburg, the editor and two anonymous reviewers for their excellent comments and suggestions. 
financial pressure. Therefore, understanding the efficacy of alternative funding strategies is a key component of the management and policy decisions regarding these public goods. The broad issue of how to increase donations to public goods has caught the attention of economists over the last few decades. The issue has been investigated mainly from the perspective of how to combine fundraising with external mechanisms, such as providing a small gift in return (e.g., Falk, 2007; Alpízar et al., 2008), information about others' donations (e.g., Frey and Meier, 2004; Shang and Croson, 2009), being observed by others (Soetevent, 2005; Alpízar and Martinsson, 2012), and information that donations will be topped up (seed money) (e.g., List and Lucking-Reiley, 2002; Huck and Rasul, 2011), where most of the results indicate that the aforementioned mechanisms increase donations. An alternative or complementary strategy would be to combine the possibility of donating with a mandatory minimum contribution to the public good by introducing a fee or a tax. The objective of this paper is to investigate the effect of different mandatory contribution levels on donations for a public good. To this end, we conducted a stated preference study to explore visitors' preferences for donating money to raise funds for a protected area given different entrance fee levels.

The early seminal work of Titmuss (1970), who claimed that blood donations would be reduced if donors were compensated, indicates that there might be a correlation between voluntary actions and money. By now there is a well-established literature on the theoretical foundations of prosocial behavior. For example, Bénabou and Tirole (2006) developed a model where behavior is explained by three main motives: extrinsic, intrinsic and reputational. The essence of this model is that not only external incentives (such as fees), but also intrinsic motivation (such as love of nature or concern for one's self-image) and how one is perceived by others affect one's behavior.

The essential problem of public goods is the propensity of subjects to free-ride. However, both introspection and massive empirical literature show that many people voluntarily contribute to public goods and do not free-ride (for findings from public goods experiments, see, e.g., Zelmer, 2003). However, the question is how donations are affected if a minimum contribution level, which for example could be motivated as a tax or a fee, is introduced. Is there a complete crowding out of voluntary donations? The public finance literature has investigated this issue from a tax perspective and generally predicts that government spending on public goods financed by lump-sum taxes completely crowds out voluntary contributions, i.e., that a tax results in a dollar-for-dollar reduction in voluntary contributions (e.g., Bergstrom et al., 1986; Andreoni, 1988). This prediction has been tested in public goods experiments conducted in a laboratory, with the general finding that an imposed lump-sum tax results in incomplete crowding out (e.g., Andreoni, 1993; Chan et al., 2002; Gronberg et al., 2012). A fee, however, is conceptually different from a tax (e.g., see findings reported in Kallbekken et al., 2011), and in this paper we are interested in exploring to what degree an entrance fee crowds out donations to a protected area. In the case of complete crowding out, there is a dollar-for-dollar reduction in donations when an entrance fee is increased. In the case of incomplete 
crowding out, on the other hand, concerns for self-image still motivate visitors to donate above and beyond the fee. Note that this paper is focused on the potential tradeoff between extrinsic and intrinsic motivations. This is in line with our research design, where respondents were not observed by others, and hence there are no reputational concerns.

The rest of the paper is organized as follows. Section 2 describes the model and the study design, section 3 presents the results, and section 4 summarizes and concludes the paper.

\section{Model and design of study}

\subsection{Model}

We apply a Lancastrian approach to model utility of a public good, in this case visiting a national park, and this assumes a multi-attribute utility function (Lancaster, 1966). Thus, the utility of a specific state of the public good is a function of the levels of the attributes, which include a monetary attribute, usually a fee, and a vector of non-monetary characteristics of the public good. However, to be able to test whether mandatory entrance fees crowd out donations, we separate the cost attributes into fee and donation. These two monetary attributes are expected to differ in their impact on utility. The reduction in available income associated with the fee can reduce the utility from the visit, and hence generates an inherently extrinsic motivation to avoid the fee. The disutility of out-of-pocket payments is still present when people choose to donate, but that effect is counteracted by the intrinsic motivation associated with willingly contributing to a good cause, e.g., warm glow (e.g., Andreoni, 1990). Thus, if an individual's behavior is guided to a larger degree by intrinsic motives, we expect the utility of donating money to be positive. Furthermore, we expect an inverted Ushaped relationship between donations and utility. This U-shape results from the combined effect of extrinsic and intrinsic motivation. The intrinsic motivation relates to the good feeling one enjoys when deciding to contribute to a good cause. However, increasing reductions in available income have the opposite effect on utility. Finally, we also explore whether the utility of donating is mediated by the introduction of an entrance fee at different levels. We expect the intrinsic motivation of donating to be negatively correlated with the level of the entrance fee. To capture this, an interaction term between donation and fee is included. Thus, below we have an indirect utility function that depends on income (Y), donations (D) and entrance fees $(\mathrm{F})$, besides the enjoyment of the attributes of the public good as captured by a vector of attributes $(\mathbf{G})$ :

$$
V=\alpha+\beta_{1} \mathrm{D}+\beta_{2} \mathrm{D}^{2}+\beta_{3} \mathrm{Y}+\beta_{4} \mathrm{~F}+\beta_{5} \mathrm{D} * \mathrm{~F}+\beta_{6} \mathrm{G} .
$$

In this formulation of the utility function for a visitor to the protected area, we expect that $\beta_{1}>0$ and $\beta_{2}<0$, which captures our hypothesis that utility increases with the initial decision to donate a positive amount, but decreases for higher donations. For entrance fees, we expect a marginal disutility of paying an entrance fee, given by $\beta_{4}<0$. 
Finally, the decision to donate will also depend on the current entrance fee levels. The term $\beta_{5}<0$ should reflect our hypothesis that the total utility from making a donation is tempered by the entrance fee levels, so that the total marginal utility from donating is lower if the entrance fees are high, i.e.,

$$
\partial \mathrm{V} / \partial \mathrm{D}=\beta_{1}+2 \beta_{2} \mathrm{D}+\beta_{5} \mathrm{~F} .
$$

The final amount donated to the national park is assumed to be a tradeoff between the disutility of taking money out of one's pocket to pay the entrance fees and donations, and the utility of feeling good from donating to a good cause.

\subsection{Design of study}

Our study is conducted in Cahuita National Park ${ }^{1}$ in Costa Rica, which is a park currently without entrance fees and where people enter multiple times in a visit to the region. ${ }^{2}$ We conduct an on-site study where we randomly sample respondents from all visitors to the park when there is no entrance fee, avoiding potential sample selection bias. Thus, the park constitutes a good case study because there is currently no entrance fee and it relies solely on donations. Cahuita National Park is located along the shoreline of the Caribbean coast of Costa Rica and attracts two main types of visitors: beach-goers and nature lovers and, to some extent, people who combined these two interests. Because Cahuita National Park attracts heterogeneous groups of visitors in terms of both country of origin and reasons for visiting the park, we also are able to investigate how heterogeneity affects the donations given different entrance fee levels.

Our research approach is based on surveying park visitors. The survey consisted of several parts. First there was a battery of socioeconomic questions and questions related to the park visit. This was followed by a choice experiment exploring visitors' donation preferences given different entrance fee levels. ${ }^{3}$ Here we also included non-monetary attributes related to proposed improvements in the park, as planned by the park authority.

In the choice experiment, each respondent made four repeated choices between two different alternatives describing what the park could be like

${ }^{1}$ Cahuita National Park is one of the most frequently visited parks in Costa Rica, with around 50,000 visitors per year from all over the world. The main entrance to the park is located on the doorstep of the town of Cahuita and receives around 95 per cent of all park visitors (a second entrance receives only 5 per cent of the visitors and charged an entrance fee of US\$6 when the study was conducted; visitors entering through this remote entrance are not included in our survey). Visitors to the park are politely invited to make a voluntary donation upon arrival, in addition to compulsory registration.

2 From the compulsory entries in the registration logbook, we can establish that, during the three months we conducted our study, an average visitor enters the park three times.

${ }^{3}$ For overviews on the choice experiment method, see, for example, Louviere et al. (2000) and Alpízar et al. (2003). 
next time they visited. Given that we included the status quo levels as part of the description of the alternatives, and that visitors had already chosen to visit the park under the status quo levels, an opt-out alternative was not included. Before the respondents were asked to make their choices in the experiment, the enumerator read a scenario to them (see the scenario in the Appendix). We used a D-optimal design allowing for interaction effects to create 40 choice sets. The 40 choice sets were blocked into 10 groups, which were then randomly allocated to the respondents. Thus, each respondent faced four choice sets, which were shown in random order to reduce potential order effects.

We interviewed people shortly after they entered the park to avoid them gaining more experience from the park. The survey was given to international visitors, either walking along the park's only trail or on the beach, from Tuesday to Saturday. ${ }^{4}$ The enumerators ${ }^{5}$ were carefully instructed to select participants without following a discernible pattern, and we regularly controlled the representativeness of the sample by comparing the sample (and enumerators' sub-samples) with the population as registered in the park's guest book during the same period, in which all visitors entering the park had to register (results shown in table 2). Moreover, the field supervisors were present in the park at all times and the quality of the fieldwork was controlled through daily debriefings and frequent monitoring.

The survey and attributes were developed in cooperation with the community and the park authority and were then refined through several focus groups and pilot studies. The alternatives were described by four attributes: use of the revenues from recreation in Cahuita National Park, information signs available, entrance fee and donation. During the pre-studies, we found that residents and international visitors have very different preferences for attributes in protected areas, which has also been found in previous studies (e.g., Chase et al., 1998; Hearne and Salinas, 2002). Thus, we focus on international visitors. ${ }^{6}$

At present, funds are used for basic park maintenance and also for small community projects ranging from environmental education to solid waste management. However, the park authority would also like to use some funds to improve the infrastructure, in particular, by constructing

${ }^{4}$ We excluded Sundays because a large fraction of visitors on this day are local residents of the town of Cahuita. Mondays had a low visiting rate, so they were used for the preparation of materials and data coding.

${ }^{5}$ In order to ensure the quality of the fieldwork, we implemented a highly ambitious training and supervision program, following the excellent advice on this topic in Whittington (2002). Enumerators went through a thorough two-week training program in which they were instructed and guided on how to conduct interviews. The training also included explaining the choice experiment method and the importance of their role as enumerators in the research process.

${ }^{6}$ Local residents of Cahuita were initially excluded since they by law would be exempt from paying an entrance fee. Further, the policy discussions at the time were focused on introducing an entrance fee for international visitors only. 
elevated trails, picnic huts and tables. ${ }^{7}$ Thus, the first non-monetary attribute in the choice experiment is the use of funds for additional park maintenance and community projects, where we included the following attribute levels: environmental education for the population of Cahuita, improved picnic huts available for visitors, and the construction of elevated trails to access the forest, including wildlife observation towers. As a second non-monetary attribute, we included the provision of information at the park, which was consistently mentioned in the focus groups and pilot studies as being an important aspect of visitors' enjoyment. Currently, information is available only at the entrance, yet one could also envision information being made available along the trails and even in a leaflet. For this attribute, we use the following levels: (i) information at the entrance on a large poster (map) describing the park's facilities; (ii) information at the entrance on a large poster (map) describing the park's facilities and information about wildlife along the trail; and (iii) information at the entrance on a large poster (map) describing the park's facilities, and a free leaflet about wildlife.

Regarding the monetary attributes, focus groups and discussions with the park authority made it clear that any attempt to charge an entrance fee of more than US\$6 would not be credible unless all the other parks in the area also increased their fees. Thus, we used entrance fee levels ranging from US $\$ 0$ to US\$6 per day. We also introduced donations as a monetary attribute ranging from US\$0 to US\$6. Table 1 summarizes the attributes and their levels, and figure 1 shows an example of a choice set.

To analyze the data from the choice experiment, we use a standard random utility approach where individuals' choices depend on the observed variables in the choice experiment and the unobserved variables that are captured in an additive error term. It is assumed that the respondents consider the two alternatives offered in every choice situation and then choose the alternative that would give them the highest utility during their next visit to the park. An individual will then prefer the generic choice alternative $\{1\}$ over choice alternative $\{2\}$ if. Hence, our econometric model is based on the following equation:

$$
\mathrm{V}^{\{1\}}-\mathrm{V}^{\{2\}}=\left[\beta_{1} \Delta \mathrm{D}+\beta_{2} \Delta \mathrm{D}^{2}+\beta_{4} \Delta \mathrm{F}+\beta_{5} \Delta(\mathrm{D} * \mathrm{~F})+\beta_{6} \Delta \mathrm{G}\right]>0
$$

We apply a random parameter logit model in Limdep in our estimations of the taste parameters to allow for heterogeneity in preferences

7 The use of funds collected at Cahuita National Park is a very salient issue, with park authorities and the authorities in the town next to the park having very different opinions regarding the use of funds. Not surprisingly, the park authorities want more expenditure in the park, and town authorities want more spending in the town. In order to keep our design as simple as possible, we limit ourselves to presenting these alternative uses of funds to the respondent, without including 'park design issues' as a separate attribute. In order to produce a relevant description of the two levels that depart from the status quo, we had extensive meetings with park authorities (to see what was relevant from their perspective) and several focus groups with park visitors (to explore what was actually demanded). 
Table 1. Attributes and attribute levels of the choice experiment

\begin{tabular}{|c|c|}
\hline Attributes & Levels \\
\hline $\begin{array}{l}\text { Financing } \\
\text { maintenance } \\
\text { and community } \\
\text { projects ... }\end{array}$ & $\begin{array}{l}\ldots \text { and environmental education for the population } \\
\text { of Cahuita (level 1, current use of funds) } \\
\ldots \text { and improved picnic huts and tables for visitors } \\
\text { (level 2) } \\
\ldots \text { and the construction of elevated trails to access } \\
\text { the forest, including wildlife observation towers } \\
\text { (level 3) }\end{array}$ \\
\hline $\begin{array}{c}\text { Information signs } \\
\text { available ... }\end{array}$ & $\begin{array}{l}\text {.. by the entrance on a large poster (map) } \\
\text { describing the park's facilities (level 1, current } \\
\text { state of information available) } \\
\ldots \text { by the entrance on a large poster (map) } \\
\text { describing the park's facilities, and information } \\
\text { signs about wildlife along the trail (level 2) } \\
\ldots \text { by the entrance on a large poster (map) } \\
\text { describing the park's facilities, and a free leaflet } \\
\text { about wildlife (level 3) }\end{array}$ \\
\hline Entrance fee & $0,1,2,3,4$, and 6 US\$ \\
\hline Donation & $0,1,2,3,4$, and 6 US\$ \\
\hline
\end{tabular}

\begin{tabular}{|l|c|c|}
\hline Characteristics & Alternative 1 & Alternative 2 \\
\hline $\begin{array}{l}\text { Funds will be used for } \\
\text { the overall maintenance } \\
\text { of the park, community } \\
\text { projects... }\end{array}$ & $\begin{array}{c}\text {.. and improved } \\
\text { picnic huts and } \\
\text { tables for visitors }\end{array}$ & $\begin{array}{c}\text {..and the construction } \\
\text { of elevated trails to } \\
\text { allow access into the } \\
\text { forest and towers to } \\
\text { observe wildlife }\end{array}$ \\
\hline & $\begin{array}{c}\text {..by the entrance; } \\
\text { there will be a } \\
\text { large sign board } \\
\text { with a map } \\
\text { describing the } \\
\text { park's facilities }\end{array}$ & $\begin{array}{c}\text {..by the entrance; there } \\
\text { will be a large sign } \\
\text { board with a map } \\
\text { describing the park's } \\
\text { facilities, as well as } \\
\text { information signs about } \\
\text { wildlife along the trail }\end{array}$ \\
\hline Entrance fee of... & 3 USD & 1 USD \\
\hline Your donation is... & 1 USD & 2 USD \\
\hline
\end{tabular}

Which alt ernative would you prefer?

\section{Alternative 1}

Alternative 2

Figure 1. Example of a choice set.

among respondents, and we account for the fact that the same individual makes four repeated choices (McFadden and Train, 2000). We use a normal distribution for the non-monetary attributes. When using the RPL and assuming normal distribution for the monetary attributes, there is a 
potential problem for the calculated willingness to pay (WTP) to have infinite moments, as discussed in Daly et al. (2012). To avoid this problem, we assume a triangle distribution and bound the monetary attribute to be 'negative'. To estimate the parameters, we rely on simulation methods because the unconditional probability that an individual chooses a particular alternative in a choice set is given by the integrals of the standard logit probabilities over all possible values of $\beta$ (for details, see Train, 2003). The model is estimated using 500 Halton draws. The application of the random parameter logit model also allows us to retrieve the individual parameters of each respondent by using the Bayes theorem (e.g., Train, 2003). In this paper, the focus is to investigate the effect of different mandatory entrance fees on donations for a public good, in this case a national park. Thus, by using the individuals' parameters, we can calculate the maximum donation for each individual, $q$, in the sample, given different entrance fees, as ${ }^{8}$ :

$$
\mathrm{D}_{\mathrm{q}}^{\max }=-\left(\frac{\beta_{1, \mathrm{q}}+\beta_{5, \mathrm{q}} * \mathrm{~F}}{2 \beta_{2, \mathrm{q}}}\right) .
$$

\section{Results}

We interviewed 769 adults from a total population of 5,182 international visitors to Cahuita National Park who visited the park during the study period of December 2007 to March 2008, with a break during the holiday season. The descriptive statistics of our selected sample and of the international visitors who were not part of the choice experiment (information was obtained from the registration book at the park entrance) are shown in table 2. By and large, our sample is representative of the population as registered in the park's guest book, in which all visitors entering the park had to register. Although the majority of the interviewed visitors are Europeans and, generally, highly educated, there are visitors from all over the world. Seventy-seven per cent of the international park visitors made a donation, similar to that stated by the visitors interviewed. The revealed average donation from the registration for the sample who took part in our survey is US $\$ 2.01$ per person, which is slightly higher than the average donation of US\$1.61 per person of those visitors who did not take part in our survey.

In our econometric analyses of the choice experiment, we code the levels of the non-monetary attributes using a dummy variable approach. The monetary attributes, i.e., donation and entrance fees, are continuous variables where the non-linearity in donation is captured by including the square of the donation attribute, as shown in equation (3). Our results from the random parameter logit model, where the data is treated as panel data, taking into account that people are doing a series of choices, are presented in table 3 . For the non-monetary attributes, visitors generally prefer provision of information along the trails in the park compared to the current information provided only at the park entrance. Yet the current financing of

${ }^{8}$ We can calculate this ratio because the scale parameter is canceled. 
Table 2. Descriptive statistics for our sample and from the registration book for the sample of international visitors who did not take part in the choice experiment

\begin{tabular}{|c|c|c|c|}
\hline & \multicolumn{3}{|c|}{ International visitors } \\
\hline & $\begin{array}{l}\text { Information from } \\
\text { registration book }\end{array}$ & $\begin{array}{l}\text { Information from } \\
\text { our survey }\end{array}$ & $p$-value ${ }^{a}$ \\
\hline Observations/respondents & 4,413 obs. & 769 resp. & \\
\hline \multicolumn{4}{|l|}{ Country } \\
\hline USA/Canada & $35 \%$ & $33.5 \%$ & 0.58 \\
\hline Latin & $7 \%$ & $6.5 \%$ & 0.60 \\
\hline \multicolumn{4}{|l|}{ America/Caribbean } \\
\hline Europe & $56 \%$ & $58 \%$ & 0.48 \\
\hline Others & $2 \%$ & $2 \%$ & 0.71 \\
\hline Male & $47.5 \%$ & $46.5 \%$ & 0.55 \\
\hline $\begin{array}{l}\text { Gave donation when } \\
\text { entering the park }\end{array}$ & $77 \%$ & $77 \%$ & 0.99 \\
\hline $\begin{array}{l}\text { Average donation per } \\
\text { person }\end{array}$ & $1.61 \mathrm{US} \$$ & $2.01 \mathrm{US} \$$ & $<0.01$ \\
\hline Average age & - & 38 years & \\
\hline \multicolumn{4}{|l|}{ Education } \\
\hline $\begin{array}{l}\text { University (with or } \\
\text { without degree) }\end{array}$ & - & $78.5 \%$ & \\
\hline \multicolumn{4}{|l|}{ Main reason for visiting } \\
\hline \multicolumn{4}{|l|}{ Cahuita National Park } \\
\hline Only beach & - & $28 \%$ & \\
\hline Only nature & - & $40 \%$ & \\
\hline Mix of both & - & $32 \%$ & \\
\hline
\end{tabular}

Notes: ${ }^{a}$ The null hypothesis is equal means in the samples.

Table 3. Random parameter logit estimations ( $p$-values in parentheses)

\begin{tabular}{|c|c|c|}
\hline & Mean coefficient & Coeff. std. \\
\hline \multicolumn{3}{|l|}{ Non-monetary attributes } \\
\hline \multicolumn{3}{|l|}{ Baseline: Environmental Education } \\
\hline Dummy: Financing picnic huts & $-1.797(<0.01)$ & $1.828(<0.01)$ \\
\hline Dummy: Financing elevated trails & $-0.494(<0.01)$ & $1.308(<0.01)$ \\
\hline \multicolumn{3}{|l|}{ Baseline: Information at Entrance } \\
\hline Dummy: Information at entrance and along trail & $0.304(<0.01)$ & $0.372(<0.01)$ \\
\hline Dummy: Information at entrance and free leaflet & $0.068(0.18)$ & $0.409(<0.01)$ \\
\hline \multicolumn{3}{|l|}{ Monetary attributes } \\
\hline Donation & $0.159(<0.01)$ & $0.466(<0.01)$ \\
\hline Donation $^{2}$ & $-0.022(<0.01)$ & $0.023(<0.01)$ \\
\hline Entrance fee & $-0.048(0.03)$ & $0.423(<0.01)$ \\
\hline Donation*Entrance fee & $-0.022(0.03)$ & $0.167(<0.01)$ \\
\hline Number of observations 3,076 & Log-likelihood function & $-1,686$ \\
\hline Number of respondents 769 & & \\
\hline
\end{tabular}


environmental education projects in the community is preferred compared to financing facilities in the park, such as picnic huts and elevated trails.

The total effect of donation on utility depends on three variables in the utility function: donation, squared donation and donation interacted with entrance fee. The overall relationship can be described as an inverted U-shaped relationship between donation and utility, because donation is positive and squared donation is negative. We find a negative utility from paying an entrance fee. ${ }^{9}$

Table 3 also reports the coefficients of the standard deviations from the mean coefficients, which indicate the degree of unobserved heterogeneity. The coefficients for the standard deviation of the parameters for the non-monetary attributes (new infrastructure and additional information) are both highly significant. Thus, although on average visitors significantly object to investments in new infrastructure in the park, there is considerable heterogeneity in their preferences, even up to the point that there is a considerable probability of sign reversal. Although visitors do show a preference for more information along the trails, there is also considerable heterogeneity around this estimate. The standard deviations of the coefficients of variables relating to entrance fees and donations are highly significant, by and large indicating that visitors have very heterogeneous preferences for entrance fees and donations. These results support our choice of the random parameter logit model.

To investigate whether entrance fees crowd out donations, we calculate individual maximum donations at different entrance fee levels using the individual parameters retrieved from the random parameter logit model. Table 4 shows the predicted average maximum donation for entrance fees in the range of US\$0 to US\$6, calculated as follows:

$$
\mathrm{D}_{\mathrm{q}}^{\max }=\max \left[-\left(\frac{\beta_{1, \mathrm{q}}+\beta_{5, \mathrm{q}} * \mathrm{~F}}{2 \beta_{2, \mathrm{q}}}\right), 0\right],
$$

which rules out negative donations, which per definition are not possible. Further, because entrance fees lower than 50 cents are rarely observed in reality, these were treated as zero donations.

In the presentation, we separate the proportion predicted to donate zero, average total donation and average conditional amount donated (i.e., amount donated given a positive donation). We find an increase in the predicted share of zero donation when the entrance fee increases. The proportion of visitors making a positive donation is significantly lower for all levels of entrance fees compared with no entrance fee. ${ }^{10}$

The predicted average conditional donation decreases as the entrance fee increases, and for all levels of entrance fee it is significantly lower compared

9 These results are robust even when we allow for correlation between the random parameters.

10 The findings regarding hypothetical bias in choice experiments are mixed. For example, Johansson-Stenman and Svedsäter (2012) found a significantly higher hypothetical marginal willingness to pay (MWTP) for an environmental good (donations to WWF) compared with a real-money MWTP, while Carlsson and 
Table 4. Predicted share of zero donations, average donation, and conditional average donation per person in US\$ given the level of entrance fee using individual parameters. p-values are presented testing the null hypothesis of equal outcomes with and without an entrance fee, at each studied entrance fee level

\begin{tabular}{|c|c|c|c|c|c|c|}
\hline & $\begin{array}{l}\text { Predicted share of } \\
\text { zero donation }\end{array}$ & $p$-values ${ }^{a}$ & $\begin{array}{c}\text { Average predicted } \\
\text { donations }\end{array}$ & p-values ${ }^{b}$ & $\begin{array}{c}\text { Average predicted } \\
\text { conditional donations }\end{array}$ & $p$-values ${ }^{c}$ \\
\hline No entrance fee & $0 \%$ & & 3.68 US\$ & & 3.68 US\$ & \\
\hline Entrance fee of 1 US\$ & $2 \%$ & $<0.01$ & 3.17 US\$ & $<0.01$ & 3.23 US\$ & $<0.01$ \\
\hline Entrance fee of 2 US\$ & $6 \%$ & $<0.01$ & 2.68 US\$ & $<0.01$ & 2.86 US\$ & $<0.01$ \\
\hline Entrance fee of 3 US\$ & $16.5 \%$ & $<0.01$ & $2.24 \mathrm{US} \$$ & $<0.01$ & $2.68 \mathrm{US} \$$ & $<0.01$ \\
\hline Entrance fee of 4 US\$ & $29.5 \%$ & $<0.01$ & 1.86 US\$ & $<0.01$ & 2.64 US\$ & $<0.01$ \\
\hline Entrance fee of 5 US\$ & $42.5 \%$ & $<0.01$ & 1.57 US\$ & $<0.01$ & 2.73 US\$ & $<0.01$ \\
\hline Entrance fee of 6 US\$ & $53 \%$ & $<0.01$ & 1.37 US\$ & $<0.01$ & $2.90 \mathrm{US} \$$ & $<0.01$ \\
\hline
\end{tabular}

Notes: ${ }^{a} p$-value from a chi-squared test, testing $\mathrm{H}_{0}$ : share of zero donations are equal between no entrance fee and the given level of entrance fee.

${ }^{b} p$-value from a $t$-test, testing $\mathrm{H}_{0}$ : average donations are equal between no entrance fee and the given level of entrance fee. ${ }^{c} p$-value from a $t$-test, testing $\mathrm{H}_{0}$ : average conditional donations are equal between no entrance fee and the given level of entrance fee. 

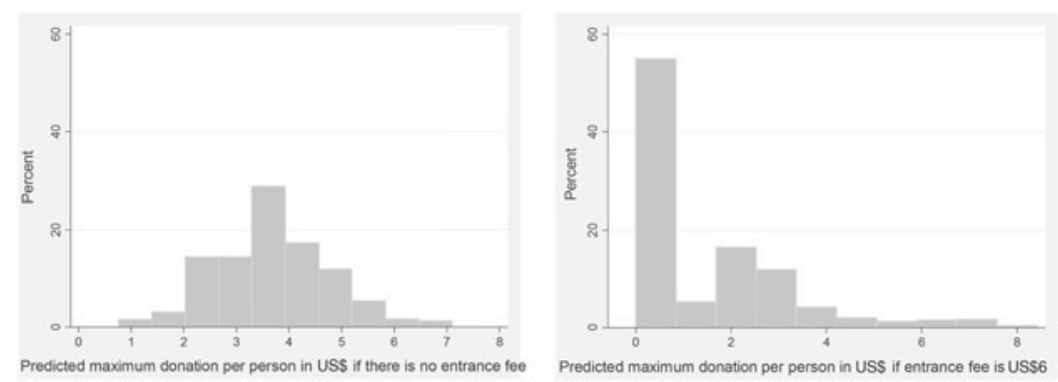

Figure 2. The left panel shows the distribution of predicted maximum donation per person in US\$ with no entrance fee. The right panel shows the distribution of predicted maximum donation per person in US\$ with an entrance fee of US\$6. The distributions are significantly different between the two entrance fee levels (chi-square p-value $<0.01$ ).

with no fee. Accordingly, the predicted average donation also decreases significantly from US\$3.68 when there is no entrance fee, to US\$1.37 when the entrance fee is US $\$ 6$. This shows an incomplete ${ }^{11}$ crowding out of donations in the sense that an increase in the entrance fee of US\$1 on average decreases donations by approximately US $\$ 0.39$, as shown in table 4 . This means that the marginal reduction in donations is less than the marginal increase in the entrance fee. Basically, what happens is that the proportion of individuals giving zero increases substantially, while the reduction in conditional donations decreases on average by only US $\$ 0.78$ when the entrance fee is increased from US\$0 to US\$6.

Figure 2 gives a detailed description of the distribution of donations with no entrance fee and with an entrance fee of 6 US\$. As can be seen, the distribution of predicted maximum donations shifts to much lower values and the proportion predicted not to give any donations climbs from zero with no entrance fee to 53 per cent with an entrance fee of 6 US\$. An overall test shows a significant difference, at the 1 per cent significance level, in the distribution of donations between the case of no entrance fee and one with an entrance fee of 6 US\$.

To check the robustness of our results, more detailed analyses are made by splitting the sample into sub-samples based on reason for visiting the park, country of origin and gender, using the individual parameters retrieved from the random parameter logit model estimated above. Incomplete crowding out of donations from introducing an entrance fee is found in all sub-samples at the 1 per cent significance level (data available upon

Martinsson (2001) found no significant difference. In our case, we find a discrepancy between stated and revealed average donation: table 2 shows an average actual donation of around US $\$ 2$, compared to the predicted average donation just over US\$3.5 when the entrance fee is zero, as shown in table 4. This discrepancy is expected to be constant between the donation levels; therefore, our estimations of the tradeoff between donation and entrance fee are still credible.

11 A complete crowding out would decrease donations by US $\$ 1$ on average for every US\$1 increase in the entrance fee. 
request). However, beach-goers are predicted to give significantly lower average donations at all entrance fee levels compared with those visiting the park to enjoy nature. Further, we tested for cultural differences in preferences regarding how to finance public goods. Visitors from countries with a culture of financing public goods through voluntary donations, i.e., visitors from the USA and Canada, are expected to experience less crowding out of donations by the introduction of an entrance fee compared with visitors from countries outside these countries, a majority of which have a tradition of financing public goods with taxes rather than visitation fees. However, we find no significant differences between these two groups of countries. Nor do we find any significant differences between men and women.

\section{Discussion and conclusions}

This paper presents the results of a choice experiment looking at the interaction, if any, between entrance fees and donations. These are two potential instruments to raise revenues to fund management and investment decisions in natural protected areas opened to tourism. Cahuita National Park in Costa Rica is a perfect setting to explore this question, because currently the park relies exclusively on donations, and because the push by the park authority to establish entrance fees is strong. Most importantly, many countries throughout the world are in the process of developing an ecotourism industry based on their natural protected areas, and the question of fees versus donations is omnipresent whenever park management authorities debate about alternative sources of revenue to fund their activities.

Our main results show that there is significant but incomplete crowding out of voluntary donations when a compulsory fee is introduced. In the conceptual framework of behavioral economics, our results show that reductions in income associated with contributing to a natural protected area have intrinsic motivations (like warm glow and self-image concerns) that make visitors donate despite facing an entrance fee. Still, we do find crowding out of voluntary behavior, which is in itself a call for attention to park authorities. In addition, we tested alternative specifications and split samples, and these results are quite robust. For example, we find that people visiting the park with swimming and sunbathing as the main purpose show more crowding out than those visiting the park for its natural attractions. Importantly, we find that visitors have very heterogeneous preferences for entrance fees and donations. We recommend that park authorities establish a gradual process to introduce new or higher entrance fees, so that information on tourists' actual preferences is revealed over time for the particular site.

An interesting insight comes from the deconstruction of the actual predicted average donation, which is the combined result of the probability of donating times the conditional donation, i.e., the amount donated by those who chose to donate a positive amount. We find that the predicted average donation decreases significantly from US\$3.68 when there is no entrance fee, to US $\$ 1.37$ when the entrance fee is US\$6, but interestingly most of this 
effect comes from a drop in the probability of donating. In other words, for many visitors there is perfect crowding, i.e., as soon as they face an entrance fee they chose not to donate. This undesirable result varies with the level of the entrance fee. For US $\$ 2$ or less, the reduction in the share of visitors donating is negligible, but it increases to almost 43 per cent and 53 per cent for entrance fees of US\$5 and US\$6. Although our study is not designed to estimate expected changes in visitation as a result of the establishment of entrance fees, this drop in the probability of donating is a strong signal to park management regarding visitors' distaste for entrance fees higher than US\$3. In fact, our recommendation to the authorities at Cahuita National Park is to start charging a conservative entrance fee of US\$2 and gather new information to decide whether to keep or eventually raise that level.

Finally, we also look at a question that is also frequently on the mind for park authorities: how much should they care about providing sophisticated infrastructure and information in an otherwise natural protected area? In line with previous studies, international visitors to natural protected areas prefer parks with less infrastructure, which allows them to have a closer interaction with nature. They do want more information along the trails. Still, it is important to add that preferences for these two attributes show considerable heterogeneity, which forces park authorities to produce innovative ideas that make the visit more comfortable, but that are not too intrusive or in conflict with the natural surroundings.

In summary, our results show that introducing compulsory entrance fees in a fundraising system previously based solely on donations is a viable way of increasing revenues in nature- based tourist activities. But as usual the devil is in the details, and park authorities must carefully fine tune the level of the entrance fee that keeps donations coming in.

\section{References}

Alpízar, F., F. Carlsson, and O. Johansson-Stenman (2008), 'Anonymity, reciprocity and conformity: evidence from voluntary contributions to a national park in Costa Rica', Journal of Public Economics 92(5-6): 1047-1060.

Alpízar, F., F. Carlsson, and P. Martinsson (2003), ‘Using choice experiments for nonmarket valuation', Economic Issues 8(1): 83-110.

Alpízar, F. and P. Martinsson (2012), 'Paying the price of sweetening your donation - evidence from a natural field experiment', Economics Letters 114(2): 182-185.

Andreoni, J. (1988), 'Privately provided public goods in a large economy: the limits of altruism', Journal of Public Economics 35(1): 57-73.

Andreoni, J. (1990), 'Impure altruism and donations to public goods: a theory of warm-glow giving?', Economic Journal 100(2): 464-477.

Andreoni, J. (1993), 'An experimental test of the public-goods crowding-out hypothesis', American Economic Review 83(5): 1317-1327.

Bénabou, R. and J. Tirole (2006), 'Incentives and prosocial behavior', American Economic Review 96(5): 1652-1678.

Bergstrom, T., L. Blume, and H. Varian (1986), 'On the private provision of public goods', Journal of Public Economics 29(1): 25-49. 
Carlsson, F. and P. Martinsson (2001), 'Do hypothetical and actual willingness to pay differ in choice experiments? Application to the valuation of the environment', Journal of Environmental Economics and Management 41(2): 179-192.

Chan, K., R. Godby, S. Mestelman, and A.R. Muller (2002), 'Crowding-out voluntary contributions to public goods', Journal of Economic Behavior \& Organization 48(3): 305-317.

Chase, L.C., D.R. Lee, W.D. Schulze, and D.J. Anderson (1998) ‘Ecotourism demand and differential pricing of national park access in Costa Rica', Land Economics 74(4): 466-482.

Daly, A., S. Hess, and K. Train (2012), 'Assuring finite moments for willingness to pay in random coefficients models', Transportation 39(1): 19-31.

Falk, A. (2007), 'Gift exchange in the field', Econometrica 75(5): 1501-1511.

Frey, B. and S. Meier (2004), 'Social comparison and pro-social behavior: testing "conditional cooperation" in a field experiment', American Economic Review 94(5): $1717-1722$.

Gronberg, T.J., R.A. Luccasen, T.L. Turocy, and J.B. Van Huyck (2012), 'Are taxfinanced contributions to a public good completely crowded-out? Experimental evidence', Journal of Public Economics 96(7): 596-603.

Hearne, R.R. and Z.M. Salinas (2002), 'The use of choice experiments in the analysis of tourist preferences for ecotourism development in Costa Rica', Journal of Environmental Management 65(2): 153-163.

Huck, S. and I. Rasul (2011), 'Matched fundraising: evidence from a natural field experiment', Journal of Public Economics 95(5): 351-362.

Johansson-Stenman, O. and H. Svedsäter (2012), 'Self-image and valuation of moral goods: stated versus actual willingness to pay', Journal of Economic Behavior \& Organization 84(3): 879-891.

Kallbekken, S., S. Kroll, and T.L. Cherry (2011), 'Do you not like Pigou, or do you not understand him? Tax aversion and revenue recycling in the lab', Journal of Environmental Economics and Management 62(1): 53-64.

Lancaster, K. (1966), 'New approach to consumer theory', Journal of Political Economy 74(2): 132-157.

List, J.A. and D. Lucking-Reiley (2002), 'The effects of seed money and refunds on charitable giving: experimental evidence from a university capital campaign', Journal of Political Economy 110(1): 215-233.

Louviere, J.J., D.A. Hensher, and J.D. Swait (2000), Stated Choice Methods: Analysis and Applications, Cambridge: Cambridge University Press.

McFadden, D. and K. Train (2000), 'Mixed MNL models for discrete response', Journal of Applied Econometrics 15(5): 447-470.

Shang, J. and R. Croson (2009), 'A field experiment in charitable contribution: the impact of social information on the voluntary provision of a public goods', Economic Journal 119(540): 1422-1439.

Soetevent, A.R. (2005), 'Anonymity in giving in a natural context - a field experiment in 30 churches', Journal of Public Economics 89(11): 2301-2323.

Titmuss, R. (1970), The Gift Relationship: From Human to Social Policy, London: Allen \& Unwin.

Train, K. (2003), Discrete Choice Methods with Simulation, Cambridge: Cambridge University Press.

Whittington, D. (2002), 'Improving the performance of contingent valuation studies in developing countries', Environmental and Resource Economics 22(1-2): 323-367.

Zelmer, J. (2003), 'Linear public goods experiments: a meta-analysis', Experimental Economics 6(3): 299-310. 


\section{Appendix: Scenario}

Thank you. Let's continue with the next part. In order to make sure that we can provide you with the best experience in Cahuita, I will ask you to do four evaluations. Here is an example of one such evaluation.

\section{(GIVE THE RESPONDENT THE EXAMPLE CARD. PLEASE POINT AT} THE EXAMPLE WHEN YOU DESCRIBE THE FOLLOWING.)

- Each card will have two different alternatives.

- Each alternative describes how Cahuita National Park could look the next time you visit.

- For each card, your task is to choose the alternative that you prefer: either Alternative one or Alternative two.

- The alternatives are described by four different characteristics.(POINT AT THE EXAMPLE CARD)

- The characteristics and the different levels are explained on this card.(TURN THE EXAMPLE CARD OVER)

- On each card you will always find these four characteristics, but you will only find one of these levels in an alternative.(POINT AT THE LEVELS) So, only the levels will change.

- The alternatives will not differ in any other aspect than those shown on the card.

- Please read them carefully.(GIVE THEM TIME TO READ)

Do you have any questions?

Let's go back to the example card. As you can see here: (POINT AT THE EXAMPLE)

- Alternative one will fund improved picnic huts and tables for visitors while Alternative two will fund the construction of elevated trails to allow access into the forestand towers to observe wildlife.

- In Alternative one there will be a large sign board with a map by the entrance describing the park's facilities, while in Alternative two there will also be information signs about wildlife along the trail.

- In Alternative one the entrance fee is $3 U S \$$ and your donation is assumed to be 1 US\$ while Alternative two has an entrance fee of 1 US\$ and your donation is assumed to be 2 US\$.

Imagine that each alternative describes how Cahuita National Park could look the next time you visit. Please look at each alternative and tell me which one you prefer. Take your time!

(MARK THE ALTERNATIVE THAT THE RESPONDENT PREFERRED ON THE EXAMPLE CARD)

\begin{tabular}{|l|l|}
\hline ALTERNATIVE & ALTERNATIVE \\
\hline 1 & 2 \\
\hline & \\
\hline
\end{tabular}

Please turn back to the explanation of characteristics and let's continue. (SHOW ONE CHOICE-SET CARD AT A TIME) 